\title{
Influence of temperature on development, reproduction and regeneration in the flatworm model organism, Macrostomum lignano
}

\author{
Jakub Wudarski ${ }^{1}$, Kirill Ustyantsev ${ }^{2}$, Lisa Glazenburg ${ }^{1}$ and Eugene Berezikov ${ }^{1 *}$ (i)
}

\begin{abstract}
Background: The free-living marine flatworm Macrostomum lignano is a powerful model organism for use in studying mechanisms of regeneration and stem cell regulation due to its combination of biological and experimental properties, including the availability of transgenesis methods, which is unique among flatworm models. However, due to its relatively recent introduction in research, many aspects of this animal's biology remain unknown. One such question is the influence of culture temperature on Macrostomum biology.

Results: We systematically investigated how different culture temperatures affect development time, reproduction rate, regeneration, heat shock response, and gene knockdown efficiency by RNA interference (RNAi) in M. lignano. We used marker transgenic lines to accurately measure the regeneration endpoint, and to establish the stress response threshold for temperature shock. We found that compared to the culture temperature of $20^{\circ} \mathrm{C}$ commonly used for $\mathrm{M}$. lignano, temperatures of $25^{\circ} \mathrm{C}-30^{\circ} \mathrm{C}$ substantially increase the speed of development and regeneration, lead to faster manifestation of RNAi phenotypes, and increase reproduction rate without detectable negative consequences for the animal, while temperatures above $30^{\circ} \mathrm{C}$ elicit a heat shock response.
\end{abstract}

Conclusions: We show that altering temperature conditions can be used to reduce the time required to establish $M$. lignano cultures, perform RNAi experiments, store important lines, and optimize microinjection procedures for transgenesis. These findings will help to optimize the design of experiments in M. lignano, and thus facilitate future research using this model organism.

Keywords: Temperature, Heat shock response, Flatworms, Macrostomum lignano, Fertility, Regeneration

\section{Background}

Flatworms (Platyhelminthes) are a large phylum in the animal kingdom (Metazoa), many of which exhibit the capacity to regenerate lost tissues and body parts [1]. This regenerative ability has long attracted the interests of scientists, and the free-living planarian flatworms (Tricladida) Schmidtea mediterranea and Dugesia japonica in particular have been studied extensively and yielded numerous insights into the mechanisms underlying regeneration [2-5]. More recently, a non-planarian

\footnotetext{
* Correspondence: e.berezikov@umcg.nl

${ }^{1}$ European Research Institute for the Biology of Ageing, University of Groningen, University Medical Center Groningen, Antonius Deusinglaan 1, 9713AV, Groningen, The Netherlands

Full list of author information is available at the end of the article
}

flatworm model Macrostomum lignano (Macrostopmorpha) has been introduced into the regeneration research arena, offering an attractive combination of experimental and biological features $[6,7]$. Macrostomum lignano is a free-living marine flatworm capable of regeneration anterior to the brain and posterior to the pharynx [8]. Similar to other flatworms, regeneration in M. lignano is made possible by stem cells called neoblasts [9]. It is a small and transparent animal that is easy to culture in laboratory conditions. These features, together with the recently reported genome and transcriptome assemblies $[10,11]$ and the development of a robust transgenesis method [12] make M. lignano a versatile model organism for research on stem cells and regeneration [7].

(c) The Author(s). 2019 Open Access This article is distributed under the terms of the Creative Commons Attribution 4.0 International License (http://creativecommons.org/licenses/by/4.0/), which permits unrestricted use, distribution, and reproduction in any medium, provided you give appropriate credit to the original author(s) and the source, provide a link to the Creative Commons license, and indicate if changes were made. The Creative Commons Public Domain Dedication waiver (http://creativecommons.org/publicdomain/zero/1.0/) applies to the data made available in this article, unless otherwise stated. 
Macrostomum lignano is a non-self-fertilizing hermaphrodite with a short generation time of 2-3 weeks [13]. When cultured in standard laboratory conditions, animals lay approximately one egg per day. Embryonic development takes five days, and hatchlings reach adulthood in about two weeks. The laid eggs are fertilized, relatively large $(100 \mu \mathrm{m})$ and follow the archoophoran mode of development [13]; i.e., they have a large, yolk-rich oocyte instead of separate yolk cells that supply a small oocyte. These properties of the eggs make them a good target for delivery of external agents, such as DNA, RNA and protein, by means of microinjection.

The possibility to introduce foreign genetic material and modify the genome of an animal is a highly sought-after experimental property, and an integral part of the genomic toolkit in model organisms commonly used for genetic research, such as the nematode Caenorhabditis elegans, fruit fly Drosophila melanogaster, yeast, and mouse, as it broadens the range of usable experimental approaches and greatly improves the chances of deciphering biological phenomena of interest. We recently demonstrated that microinjection of DNA into single-cell stage embryos can be used to generate transgenic M. lignano animals [12]. The technique is efficient and robust, and stable transgenic lines can be obtained within three-to-four months, including F1 and F2 crosses. However, from the experimental perspective, it would be advantageous if the time required to generate transgenic animals could be shortened. Manipulation of culture temperature conditions is one way to approach this challenge.

Temperature is one of the most important factors influencing most biological processes. The overall range of temperatures that support active life on Earth stretches from as low as $-1.8^{\circ} \mathrm{C}$ in polar regions to around $113^{\circ} \mathrm{C}$ for thermophilic archaea at the other extreme $[14,15]$. Most animals have specific temperature ranges that are optimal to their growth; this is because even small alterations in the temperature can lead to significant changes in animal metabolism. If these changes are sustainable for the organism, the increase in the temperature usually leads to an increase in the speed of physiological processes. The most common way of showing this relationship is using the temperature coefficient Q10 $=($ Rate $2 /$ Rate 1$)^{10 /(\text { Temperature } 2 \text {-Temperature } 1)}$, which compares the rates of a process at a given temperature with the rate at temperature increased by $10^{\circ} \mathrm{C}$ [16]. The most popular way of using the Q10 index is by measuring oxygen consumption [17], but it may also be applied to various different measurements, such as electric organ discharge [18] or locomotor performance [19].

All living organisms respond to changes in environmental temperature. Perturbations in temperature will usually trigger the heat shock response pathway, which is an ancient, universal mechanism based on specialized chaperone molecules called heat shock proteins, or Hsps [20]. These proteins can help other proteins to fold correctly, repair damaged proteins, or degrade them. They can also be a good indicator of stress that an organism undergoes [21].

Here we present how temperature affects development, growth, fertility, and regeneration capabilities of Macrostomum lignano. We tested the stress response to elevated temperatures by measuring the activity of the Heat shock 20 (Hsp20) gene using qRT-PCR and Hsp20::mScarlet transgene expression. Furthermore, we measured the hatching speed of $M$. lignano eggs when incubated at different temperatures, as well as the number of offspring produced in these conditions. We also investigated how changes in temperature influence regeneration speed in $M$. lignano, and the speed of the development of phenotypes upon gene knockdown by RNA interference (RNAi). Our findings establish optimal conditions for M. lignano cultures and will help inform future research using this model organism, particularly for creating transgenic animals and performing RNAi experiments.

\section{Materials and methods}

\section{Strains}

The DV1 inbred M. lignano line used in this study has been described previously [10, 22, 23]. The NL10 and NL22 lines were previously established in our laboratory [12]. Animals were cultured under laboratory conditions in plastic Petri dishes (Greiner), filled with nutrientenriched artificial seawater (Guillard's $\mathrm{f} / 2$ medium). Worms were fed ad libitum on the unicellular diatom Nitzschia curvilineata (Heterokontophyta, Bacillariophyceae) (SAG, Göttingen, Germany). Conditions in the climate chambers were set at $20^{\circ} \mathrm{C}, 25^{\circ} \mathrm{C}, 30^{\circ} \mathrm{C}$ and $35^{\circ} \mathrm{C}$ with constant aeration, and a $14 \mathrm{~h} / 10 \mathrm{~h}$ day/night cycle.

The heat shock sensor construct KU\#49 was created using a previously described double-promoter vector approach [12]. The promoter region of M. lignano hsp20 homolog gene (Mlig005128.g2) was cloned using primers 5' -GGATGGATCCTCATTTATAAGCGTACCGTACT-3' and 5 '-TTATAAGCTTCATGCTGTTGTTGACTGGC GTA-3' to drive expression of mScarlet-I red fluorescent protein, while elongation factor 1 alpha $(E F A)$ promoter driving expression of NeonGreen fluorescent protein was used for the selection of transgenic animals. Two hundred thirty-five single-cell eggs were injected with the KU\#49 plasmid as previously described [12], but without radiation treatment. Hatchlings were selected based on the presence of green fluorescence, and a stable transgenic line NL28 was established.

\section{Egg hatching}

Twenty single-cell stage eggs per temperature condition were picked and transferred to single wells in a 6-well 
plate. They were monitored daily, and hatched worms were immediately removed from the test well. Each temperature condition was tested independently in triplicate.

\section{Heat shock}

To measure expression levels of the Mlig-hsp 20 gene by qRT-PCR, 50 worms of the same age were selected for each of the three replicates. Animals were incubated for two hours at different temperatures $\left(20^{\circ} \mathrm{C}, 25^{\circ} \mathrm{C}, 33^{\circ} \mathrm{C}\right.$, $34{ }^{\circ} \mathrm{C}$ and $35^{\circ} \mathrm{C}$ ) and two more hours at $20^{\circ} \mathrm{C}$, before RNA extraction (RNeasy, Qiagen). Quantitative RT-PCR was done using the Light Cycler 480 (Roche) with 5'-CGAAGATGTCACTGAGGTCAAG-3' and 5'-GCG CCTGCAGTAGAAGAAT-3' as primers and GAPDH, COX and EIF as reference target genes, as previously described [24]. Analysis of the results was performed using the qBase+ software (Biogazelle).

To monitor heat shock response using Hsp20::mScarlet transgene, NL28 transgenic animals were incubated for 2 $\mathrm{h}$ at different temperatures $\left(20^{\circ} \mathrm{C}, 25^{\circ} \mathrm{C}\right.$ to $35^{\circ} \mathrm{C}$ with $1{ }^{\circ} \mathrm{C}$ interval, and $37^{\circ} \mathrm{C}$ ), followed by $22 \mathrm{~h}$ at $20^{\circ} \mathrm{C}$, and then imaged using Zeiss Axio Zoom V16 microscope with an HRm digital camera and Zeiss filter sets 38HE (FITC) and 43HE (DsRed). Images were analyzed using ImageJ software. Images were converted to 8-bits, the area of the worm was selected, and the median value of the signal was measured and visualized using box plot. Graphs were generated using the ggplot2 package for R.

\section{Reproduction}

Three sets of 20 freshly hatched worms were selected per line and temperature condition. They were kept in the selected temperature until the end of the experiment, a total duration of five weeks. Twice per week, the worms were transferred to new plates with fresh food, and the old plates, where animals laid eggs in the preceding time interval, were incubated until all eggs were hatched, after which the hatchlings were counted. The approach of counting hatchlings as a proxy to the number of laid eggs rather than the direct counting of eggs was chosen because it is easier and more reliable to count hatchlings than to count egg clumps.

\section{Regeneration}

Twelve NL22 worms expressing GFP marker in testes [12] were used per condition and cut above the testes. The worms were then placed in 12-well plates with fresh diatom and monitored daily. The days of the first appearance of GFP signal in the testes and in the seminal vesicle were noted and used to measure the time required for regeneration.

\section{RNA interference}

For the knockdown of Mlig-ddx39 gene, 15 worms per temperature condition $\left(20^{\circ} \mathrm{C}, 25^{\circ} \mathrm{C}\right.$ and $\left.30^{\circ} \mathrm{C}\right)$ were selected and treated with Mlig-ddx39 dsRNA fragments as previously described [11]. The morphology and viability of the worms was monitored on a daily basis and any abnormalities were noted. GFP dsRNA was used as a negative control. For measuring the efficiency of Mlig-ddx-39 knockdown, qRT-PCR was performed in the same way as described above for the Mlig-hsp20 gene but with Mlig-ddx39 primers 5'-ACCCAGAGC TGCTGGACTAT-3' and 5'-GTAGGAGCCCTTGT GACCTG-3'. For the knockdown of Mlig-sperm1 gene, twenty worms per temperature condition were treated with Mlig-sperm1 dsRNA fragments as previously described [25], and the number of animals with the enlarged testes were counted on day 4 of the treatment.

\section{Results}

\section{Establishing the temperature range}

Commonly used laboratory conditions for Macrostomum lignano cultures are as follows: temperature of $20^{\circ} \mathrm{C}$, humidity $60 \%$, and light/dark cycle of $14 \mathrm{~h} / 10 \mathrm{~h}$. These conditions were chosen mainly because they are optimal for the growth of the diatom Nitzschia curvilineata, which is the main food source for the worms [26]. To assess the temperature conditions that can be used in the experiment, we first established the temperature range in which the worms survive. While freezing the worms proved to be lethal, they could survive when kept at $4{ }^{\circ} \mathrm{C}$ for at least two weeks. However, because the diatom does not grow in these conditions, we decided to exclude $4{ }^{\circ} \mathrm{C}$ from further experiments. Other temperatures below $20^{\circ} \mathrm{C}$ were also excluded from the experiment, since the primary objective of the study was to find conditions that accelerate growth and development. On the other side of the temperature spectrum, the worms dissolve when kept at $42{ }^{\circ} \mathrm{C}$ for two hours, and died after one week of culture at $37^{\circ} \mathrm{C}$. Therefore, we have decided to use $20^{\circ} \mathrm{C}, 25^{\circ} \mathrm{C}, 30^{\circ} \mathrm{C}$ and $35^{\circ} \mathrm{C}$ as our experimental conditions to study long-term temperature effects on $M$. lignano (Fig. 1).

\section{Heat shock response}

To investigate which temperatures induce stress response in the worms, we monitored the activity of the heat shock 20 promoter (Mlig-hsp20). First, we performed a quantitative RT-PCR to measure the expression level of Mlig-hsp 20 at $20^{\circ} \mathrm{C}, 25^{\circ} \mathrm{C}, 30^{\circ} \mathrm{C}, 33^{\circ} \mathrm{C}, 34^{\circ}$ $\mathrm{C}$ and $35^{\circ} \mathrm{C}$. There was no significant difference in the expression level of $\mathrm{Hsp} 20$ between $20^{\circ} \mathrm{C}$ and $25^{\circ} \mathrm{C}$ (Fig. 2a). However, a small (2-fold), but significant $(P=$ $0.027, t$-test), increase in the expression was observed at $30{ }^{\circ} \mathrm{C}$ compared to $20^{\circ} \mathrm{C}$ (Fig. 2a). More than a ten-fold raise in the expression level was observed at $33^{\circ} \mathrm{C}$, which increased to more than 100 -fold at the highest tested temperature of $35^{\circ} \mathrm{C}$ (Fig. 2a). In the second test 


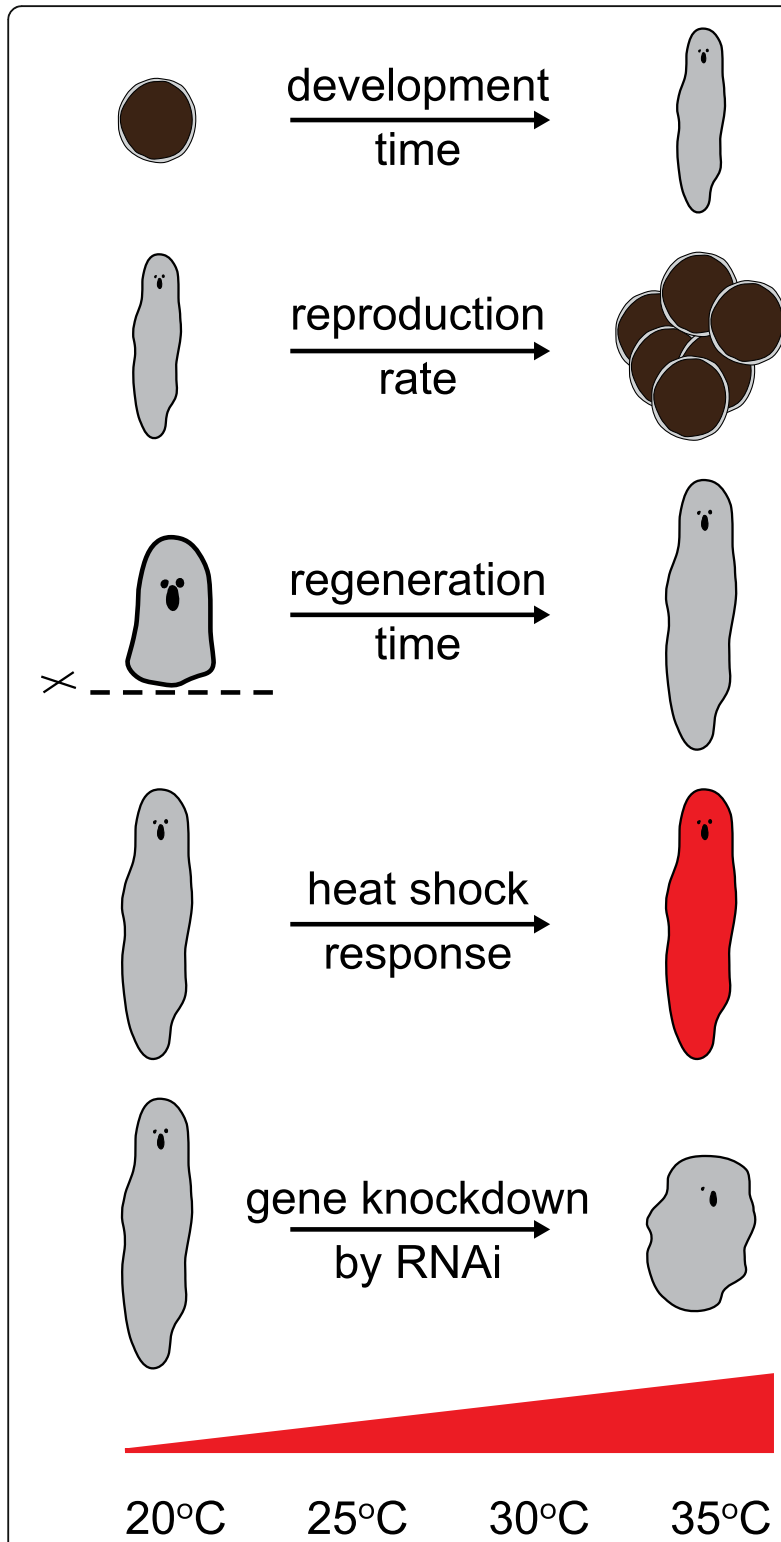

Fig. 1 Design of the study. Embryos and animals of two wild-type strains, DV1 and NL10, were cultured at a range of temperatures from $20^{\circ} \mathrm{C}$ to $35^{\circ} \mathrm{C}$ and development time, reproduction, regeneration time, heat shock response and efficiency of gene knockdown by RNA interference were measured

we created a transgenic line expressing $\mathrm{mScarlet}-\mathrm{I}$ protein under the control of the Mlig-hsp20 promoter (Fig. 2b) and measured the level of fluorescence $24 \mathrm{~h}$ after a $2-\mathrm{h}$ incubation at different temperatures ranging from $20^{\circ} \mathrm{C}$ to $37^{\circ} \mathrm{C}$ (Fig. 2c, d). More than two- and ten-fold increase in the fluorescence was observed at $34^{\circ} \mathrm{C}$ and $37^{\circ} \mathrm{C}$ respectively (Fig. 2c).

\section{Speed of embryonic development}

According to Morris et al. [13], it takes around $120 \mathrm{~h}$ (five days) for Macrostomum eggs to fully develop when eggs are kept at $20^{\circ} \mathrm{C}$. To investigate how the temperature affects the speed of embryonic development and hatching, we picked freshly laid embryos and monitored their development until hatching at different temperatures. To investigate potential differences due to genetic background, we used two M. lignano lines that are currently used in a majority of studies on $M$. lignano, the DV1 and NL10 lines. These lines are independently derived from wild-type populations from the same geographical location and differ by a whole-chromosome duplication but otherwise behave very similarly under laboratory conditions [12]. We first studied the effect of low temperature. At $4{ }^{\circ} \mathrm{C}$ the development of the eggs is arrested and they can be stored for at least one month, and resume their development once returned to higher temperatures. Next, we studied how quickly the eggs develop at temperatures between $20{ }^{\circ} \mathrm{C}$ and $35^{\circ} \mathrm{C}$. As shown in Fig. 3, when kept at standard conditions $\left(20^{\circ} \mathrm{C}\right)$ the eggs started to hatch after six days. Increase in the temperature resulted in proportionally faster embryonic development and earlier hatching, which was two times faster at $35^{\circ} \mathrm{C}$ compared to $20^{\circ}$ $\mathrm{C}$ and took only three days. Of note, about $10 \%$ of eggs remain unhatched after eight days of incubation at $20^{\circ} \mathrm{C}$, compared to less than $5 \%$ at higher temperatures, suggesting that even the highest tested temperature of $35^{\circ} \mathrm{C}$ does not have detrimental effects on the survival of embryos.

\section{Reproduction}

The reproduction rate is a very important factor for a model organism, since animals with shorter generation time enable faster generation of data in genetic experiments. In addition, if animals produce large numbers of offspring, the generated data will, in most cases, have higher statistical power.

To assess the temperature impact on M. lignano reproduction rate we have compared the number of offspring generated over the course of five weeks by worms kept at different temperature conditions. The experiment was started with hatchlings to incorporate postembryonic development in the study, and both DV1 and NL10 line were used. It took the hatchlings of both lines three weeks to grow and produce first progeny at $20^{\circ} \mathrm{C}$, while at $25^{\circ} \mathrm{C}$ hatchlings were observed in two weeks for NL10 line but not for DV1. At $30^{\circ} \mathrm{C}$ and $35^{\circ} \mathrm{C}$ both lines produced progeny already after two weeks (Fig. 4). From three weeks onwards, the number of hatchlings produced per week increased from below 200 at $20^{\circ} \mathrm{C}$ to more than 300 in temperatures above $20^{\circ} \mathrm{C}$; hatchling numbers were highest for worms kept at $30^{\circ} \mathrm{C}$. This was true for both genetic backgrounds, and we did not 


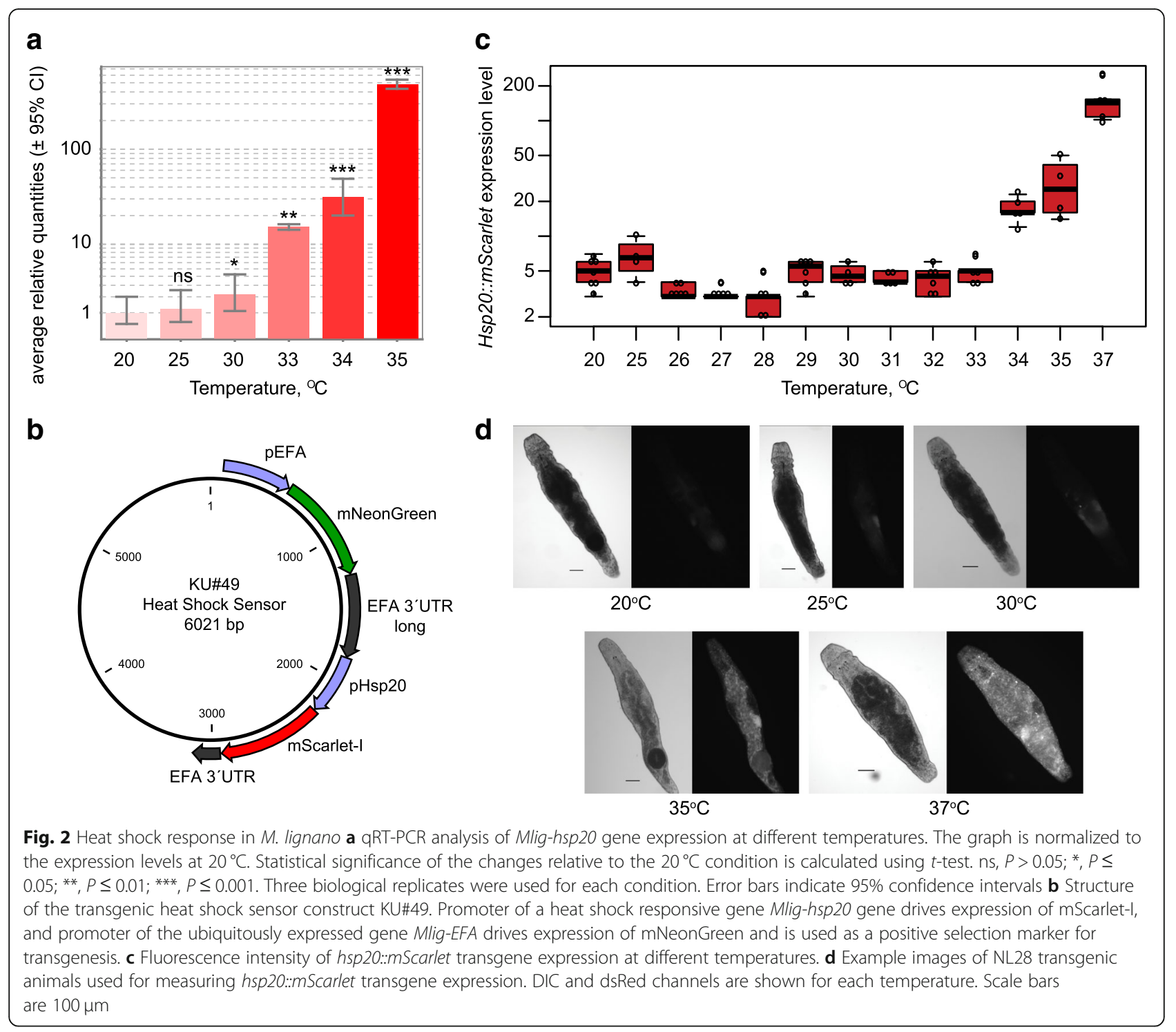

observe significant differences between DV1 and NL10 lines (Fig. 4).

Although temperatures of $30^{\circ} \mathrm{C}$ and higher resulted in more hatchlings, it also activates a heat shock response (Fig. 2). To investigate the long-term effect of the elevated temperature and potential stresses that it can have on the worms, we kept the worms at the selected temperatures and monitored for morphological aberrations after three and six months of culturing. Worms kept at $25^{\circ} \mathrm{C}$ showed no morphological changes at both check points as compared to the worms kept at $20^{\circ} \mathrm{C}$ (Fig. 5). However, for both the $30^{\circ} \mathrm{C}$ and $35^{\circ} \mathrm{C}$ temperature conditions, various aberrations in the general morphology were observed. After three months an increased number of cysts, damaged tissue and enlarged testes were commonly present in both DV1 and NL10 lines (Fig. 5). None of the worms kept at $35{ }^{\circ} \mathrm{C}$ survived until the six-month checkpoint, and all worms that survived at $30^{\circ} \mathrm{C}$ showed morphological aberrations (Fig. 5). Therefore, prolonged exposure to the temperatures above $30^{\circ}$ $\mathrm{C}$ is detrimental for M. lignano.

\section{Regeneration time}

Since the main attraction of $M$. lignano as a model organism is its regenerative ability, we next studied how temperature influences regeneration. It is commonly accepted that higher temperature leads to increases in overall metabolic activity [16]. To evaluate the influence of the temperature on the time needed for a worm to fully regenerate its body after amputation above the testes region, we tracked the regeneration of testes and the appearance of sperm in the vesicular seminalis using a previously established transgenic line NL22, which expresses GFP under the control of the testes- and 


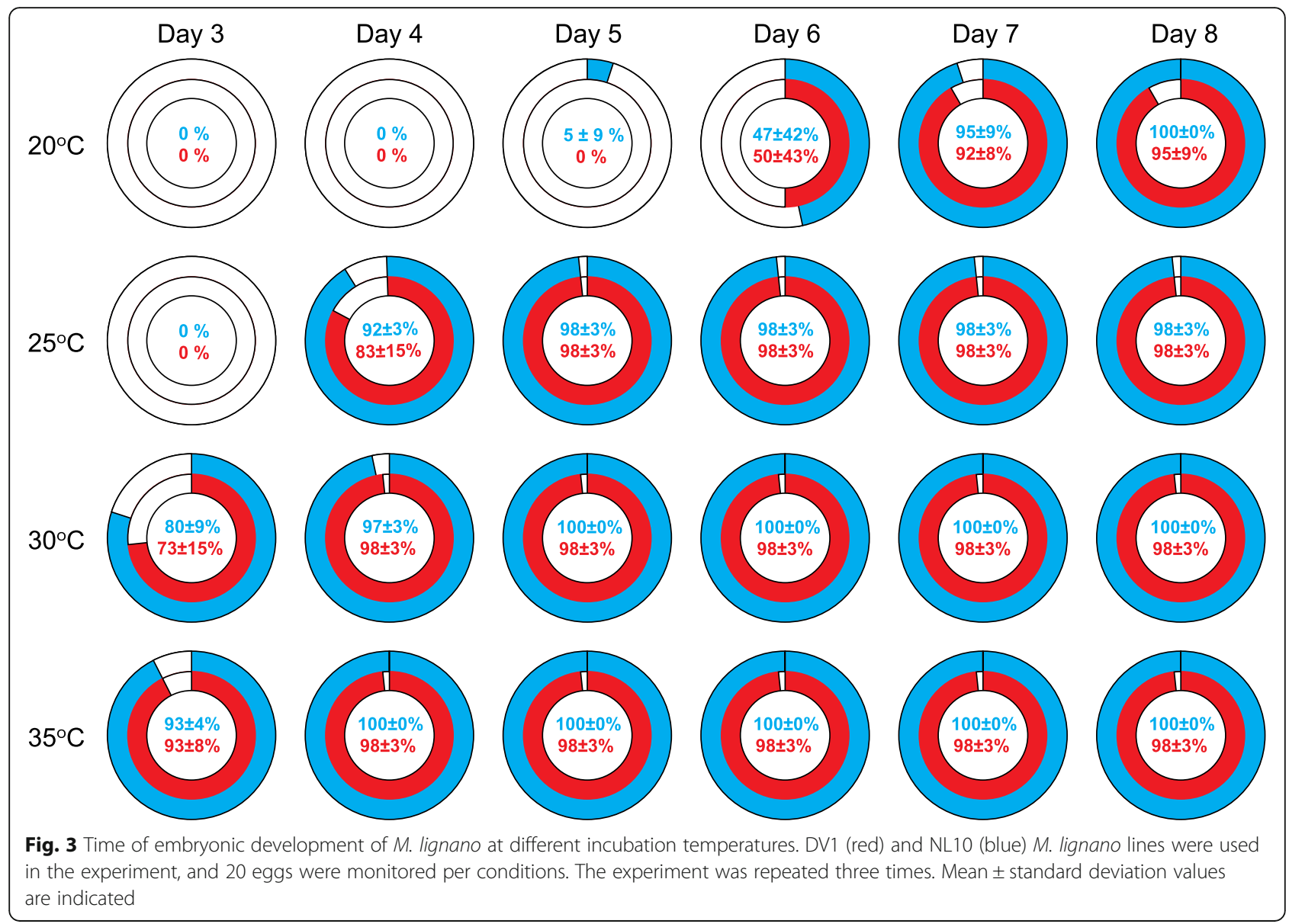

sperm-specific ELAV promoter [12]. Using such a transgenic marker provides better precision, consistency and efficiency in assaying the extent of regeneration. Indeed, we observed no significant variation when assessing the time of appearance of GFP signal after amputation at all tested temperatures (Table 1).

As expected, the speed of regeneration increased with temperature (Table 1). If we take the regeneration time at $20^{\circ} \mathrm{C}$ as the standard rate, then for the regeneration of testes the calculated temperature coefficients are Q10 $=4$ at $25^{\circ} \mathrm{C}$ and $\mathrm{Q} 10=3$ for $30^{\circ} \mathrm{C}$ and $35^{\circ} \mathrm{C}$. This shows that the largest effect is obtained when increasing the temperature to $25^{\circ} \mathrm{C}$, and the fastest regeneration takes place at $30^{\circ} \mathrm{C}$, without further benefit of increased temperature on the regeneration time. Hence, temperatures of $25^{\circ} \mathrm{C}$ and $30^{\circ} \mathrm{C}$ ought to be considered in

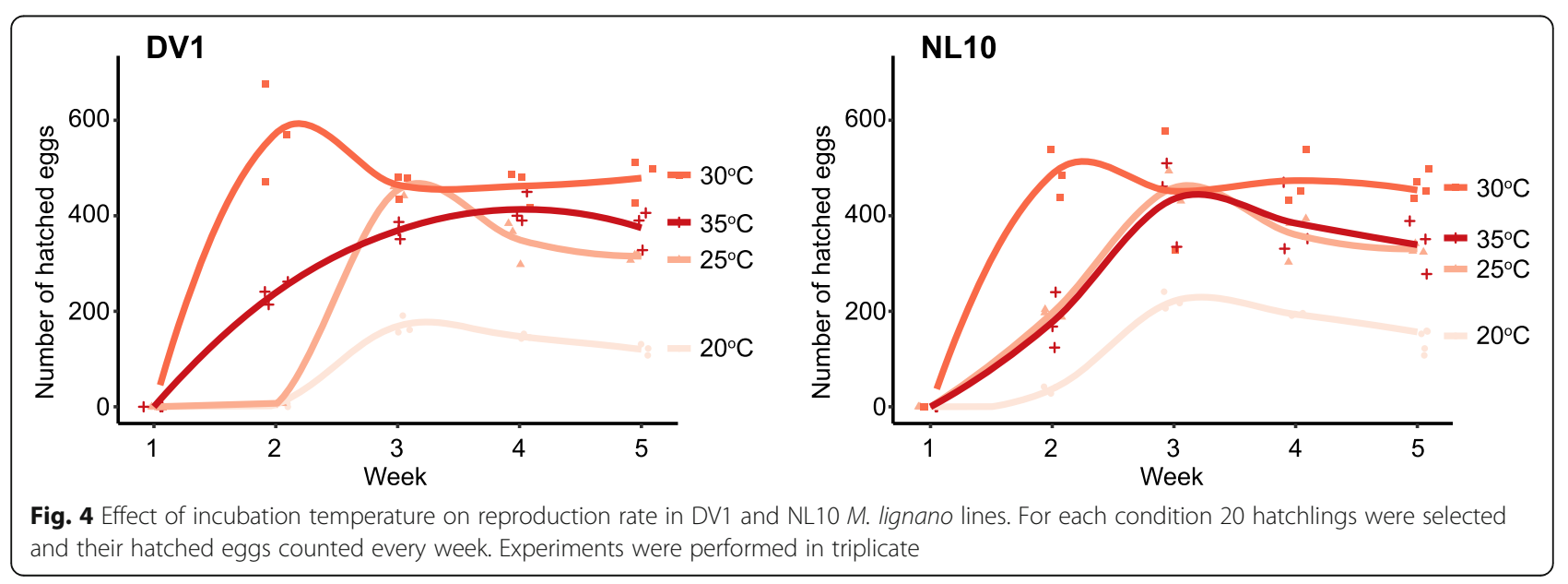




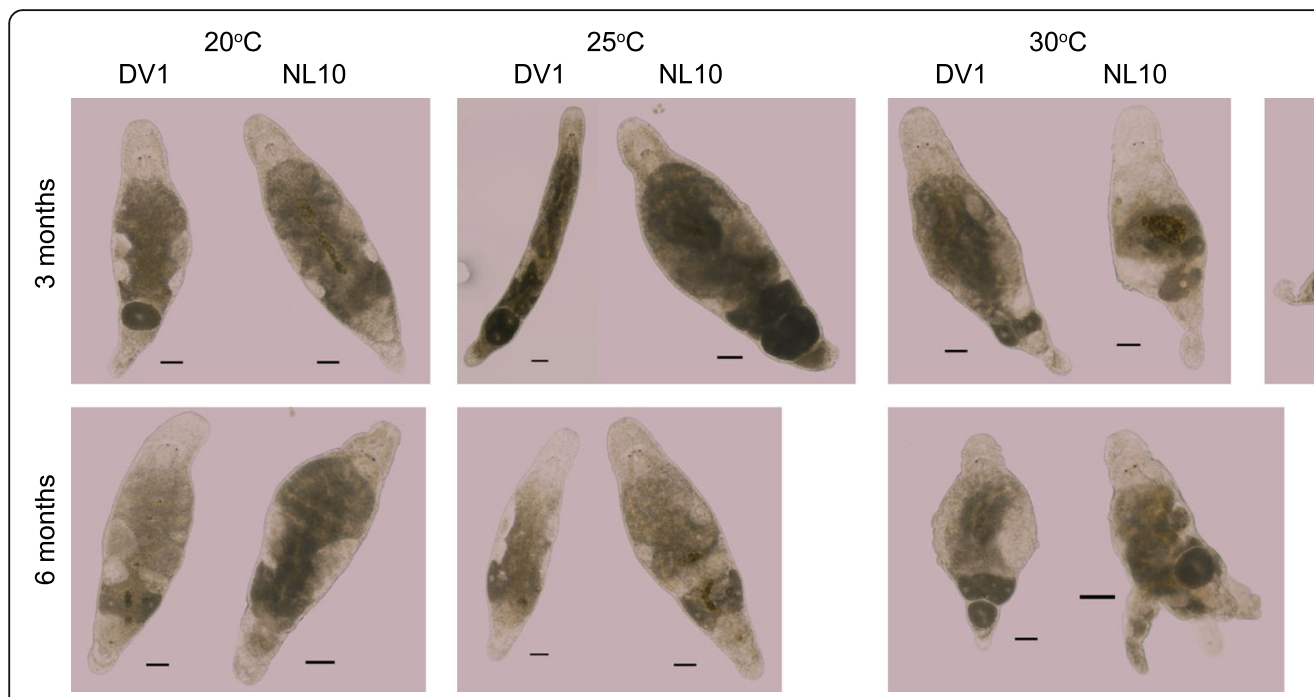

Fig. 5 Effects of prolonged exposure to high temperatures on morphology in M. lignano. No visible abnormalities after incubation at $20^{\circ} \mathrm{C}$ or $25^{\circ}$ C for up to 6 months. Scale bars are $100 \mu \mathrm{m}$

regeneration experiments on M. lignano, as it shortens the duration of an experiment by two to three times (Table 1).

\section{RNA interference}

Knockdown of gene expression by RNA interference (RNAi) is currently the primary approach for loss-of-function studies in M. lignano [7]. In this approach animals are soaked with double-stranded RNA against the target gene, and often prolonged treatments for several weeks are required to observe a phenotype [11, 25, 27]. We have tested how temperature influences the speed of phenotype development upon RNAi treatment. To do this, we knocked down Mlig-ddx39, a gene known for its function in cell proliferation in M. lignano and a robust lethal knockdown phenotype [11]. Similarly to the reproduction test, we used the DV1 and NL10 lines for this experiment (Table 2). At $20^{\circ} \mathrm{C}$, it took around 20 days for all animals to die upon Mlig-ddx39 knockdown. When worms were kept at higher temperatures, death occurred faster: at 11 and 8 days for worms kept at $25^{\circ} \mathrm{C}$ and $30^{\circ} \mathrm{C}$ respectively. There was no visible difference between the two strains used for the experiment (Table 2). Next, we investigated

Table 1 Effect of temperature on the speed of regeneration

\begin{tabular}{lll}
\hline Temperature & Regeneration time, days & \\
\cline { 2 - 3 } & Testes & Sperm \\
\hline $20^{\circ} \mathrm{C}$ & 6 & 8 \\
$25^{\circ} \mathrm{C}$ & 3 & 5 \\
$30^{\circ} \mathrm{C}$ & 2 & 3 \\
$35^{\circ} \mathrm{C}$ & 2 & 3 \\
\hline
\end{tabular}

${ }^{a}$ no variation was observed, standard deviation $=0$ in all conditions. NL22 transgenic line, which is based on DV1 line, was used in the experiments whether the observed increase in the speed of manifestation of the $d d x 39$ RNAi phenotype at higher temperatures is atrributable to higher efficiency of gene knockdown by RNAi, or to other factors. For this, we measured by qRT-PCR the abundance of Mlig-ddx39 transcripts at different time points after the start of the RNAi experiment at different temperatures (Fig. 6). Animals treated with dsRNA against $g f p$ were used as reference controls. At all tested temperatures no significant variations were observed in the expression levels of Mlig-ddx39 between control samples during the course of the experiment (Fig. 6). At the same time, for the Mlig-ddx39 dsRNA treated animals a drop of $\sim 80 \%$ in the level of $d d x 39$ transcripts was observed already after one day of treatment at $20^{\circ} \mathrm{C}$ or $25^{\circ} \mathrm{C}$, and even a higher drop of $\sim 90 \%$ at $30^{\circ} \mathrm{C}$. However, at subsequent days, the knockdown levels stabilized at around 95\% at all temperatures. Thus, we conclude that the kinetics of RNAi itself is not significantly affected by temperature. Instead, the observed shortening of time for the manifestation of the Mlig-ddx39 RNAi phenotype at higher temperatures can be explained by the increased rate of cell turnover.

To test whether the acceleration of the development of RNAi phenotypes at elevated temperatures can be generalized to other genes, we investigated Mlig-sperm1 gene, knockdown of which leads to abnormal sperm morphology and enlarged testes [25]. This is a slow RNAi phenotype that takes $2-3$ weeks to develop at $20^{\circ}$ $\mathrm{C}$ [25]. To quantify the extent of the phenotype at different temperatures, at day 4 of RNAi treatment we counted the fraction of animals with testes enlarged to the extent that they were touching each other. (Fig. 7). Similar to the results with Mlig-ddx39 RNAi, higher temperatures resulted in faster development of the 
Table 2 Effect of temperature on the development of RNAi phenotypes

\begin{tabular}{llll}
\hline Temperature & $\begin{array}{l}\text { Incubation time with } \\
\text { dsRNA against Mlig-ddx39 } \\
\text { gene until lethality }{ }^{\mathrm{a}} \text { days, } \\
\text { mean } \pm \text { standard deviation }\end{array}$ & $\begin{array}{l}\text { Percentage of animals } \\
\text { with enlarged testes } \\
\text { after 4 days of incubation } \\
\text { with dsRNA against } \\
\text { Mlig-sperm1 gene } \\
\text { NL10 }\end{array}$ \\
\cline { 2 - 4 } & DV1 & NL10 & $0 \%$ \\
\hline $20^{\circ} \mathrm{C}$ & $17.8 \pm 1.3$ & $16.6 \pm 1.9$ & $25 \%$ \\
$25^{\circ} \mathrm{C}$ & $10.1 \pm 0.6$ & $9.5 \pm 0.5$ & $25 \%$ \\
$30^{\circ} \mathrm{C}$ & $7.9 \pm 0.2$ & $7.2 \pm 0.4$ & $85 \%$
\end{tabular}

${ }^{a}$ no lethality was observed at the tested temperatures when incubating animals with dsRNA against $g f p$ as a control

${ }^{b}$ when testes touch each other

phenotype, and while no sufficiently enlarge testes were observed after four days of dsRNA treatment at $20{ }^{\circ} \mathrm{C}$, 25 and $85 \%$ of the animals had developed enlarged testes at $25^{\circ} \mathrm{C}$ and $30{ }^{\circ} \mathrm{C}$ respectively (Table 2 ). Hence, similar to regeneration, RNAi phenotypes can be accelerated with temperature in M. lignano and higher temperatures can be used to shorten the duration of experiments.

\section{Discussion}

Temperature is a key factor in the husbandry of laboratory animals, and knowing the optimal values helps to provide them with the most suitable conditions. Changing the temperature has long been used as a method to influence the growth of model organisms, as best seen in the case of C. elegans [28, 29], and recently the role of temperature in the biology of planarian flatworm Schmidtea mediterranea was investigated [30].

Here we tested how different temperatures affect the biology of the flatworm Macrostomum lignano (Table 3).
While worms can be kept at $4{ }^{\circ} \mathrm{C}$ for two weeks, freshly laid eggs can be stored in these conditions for much longer. For practical purposes, this is useful for back-up and long-term storage of valuable worm cultures, such as transgenic lines, and for collection and synchronization of eggs for subsequent microinjection. The ability to collect one-cell stage eggs and prevent their division by keeping them on ice or in a refrigerator provides a wider time window for microinjections, as it allows separation of egg picking from injection. At the same time, higher temperatures speed-up the development and shorten the time required for the worms to hatch. Incubating the eggs at $25^{\circ}$ $\mathrm{C}$ or $30^{\circ} \mathrm{C}$ can save several days of unnecessary waiting time, enabling faster generation of transgenic animals.

Standard M. lignano cultures are kept at $20^{\circ} \mathrm{C}$ and are transferred to fresh diatom every week, or twice a week when cultures are used for egg production for microinjections [12]. In this way, a new population of worms can be expanded every two weeks if the starting culture is sufficiently dense. The generation time of two weeks can be quite limiting when experiments require large numbers of specimens, or when the starting culture has a small number of animals. This is often the case for establishing a new transgenic line, performing in situ hybridization, RNAi experiment or isolating nucleic acids and proteins. Increasing overall egg production by simply putting the cultures at higher temperature can be used as an easy method to quickly generate a large number of worms. However, one must be cautious to avoid undesirable stress response that could potentially lead to distorted results. While keeping the animals at $30{ }^{\circ} \mathrm{C}$ can result in a significant increase in the egg production, the changes in the morphology, visible already after three

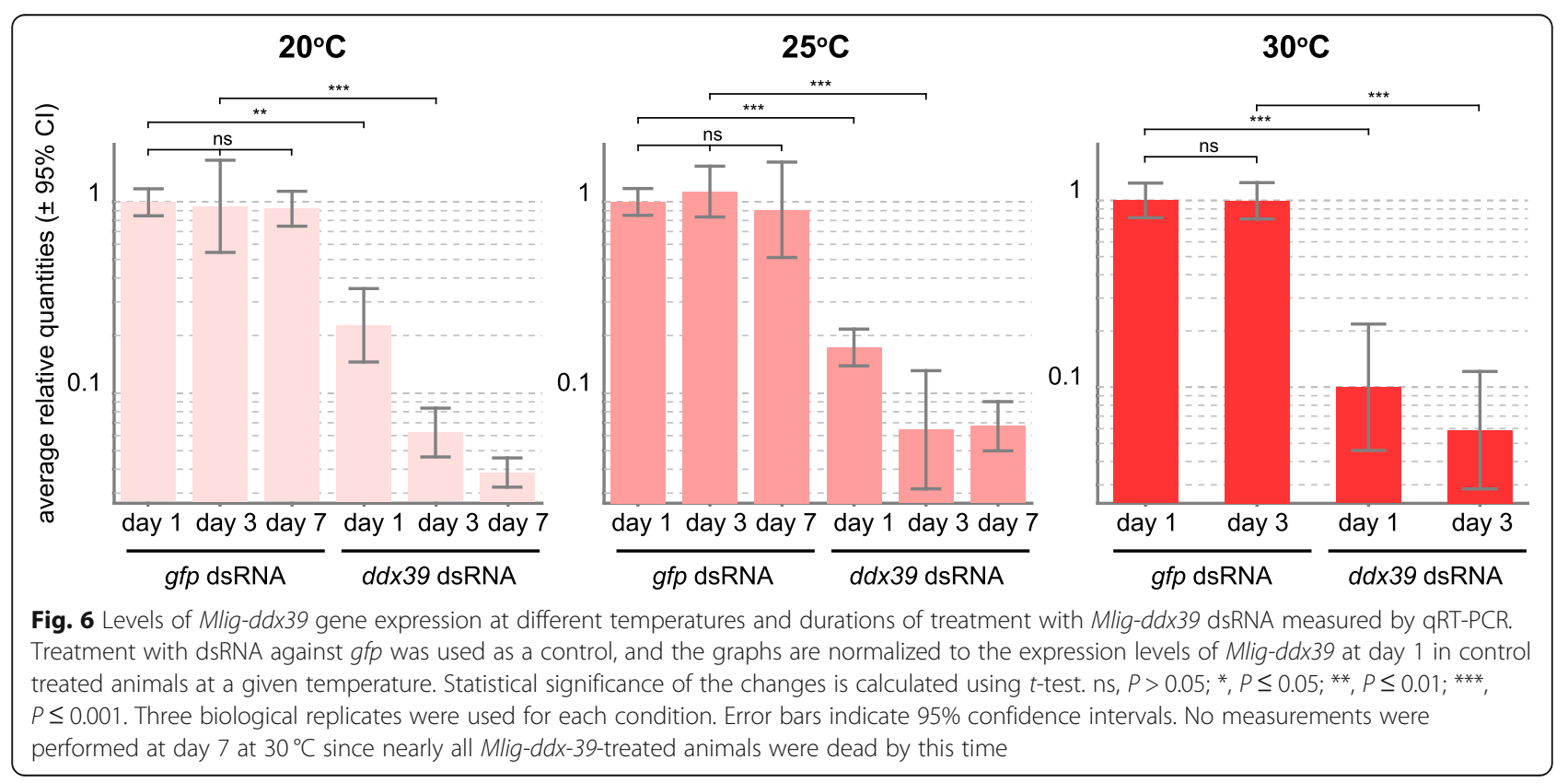




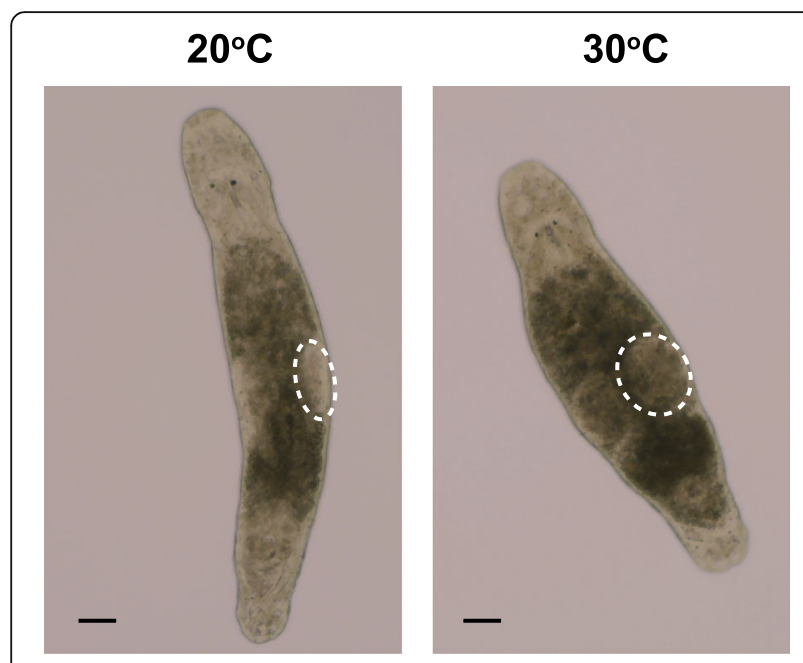

Fig. 7 Phenotype of Mlig-sperm 1 knockdown after four days of treatment with dsRNA. Note the difference in testes size (dashed lines) between $20^{\circ} \mathrm{C}$ and $30^{\circ} \mathrm{C}$. Scale bars are $100 \mu \mathrm{m}$

months, indicate that these conditions may cause too much stress to the worms. Indeed, we observed mild heat shock response activation at $30^{\circ} \mathrm{C}$, which quickly increases with further rising of incubation temperature.

Regeneration is one of the most prominent features of flatworms, and M. lignano provides a powerful experimental platform to study this phenomenon. We demonstrate that speed of regeneration increases with temperature in $M$. lignano, which can be taken into account and used to shorten time required for an experiment when needed. Similarly, gene knockdown by RNA interference is temperature-dependent and RNAi experiments can be accelerated by increasing the temperature. Importantly, the efficiency of gene knockdowns itself is not substantially affected by temperature, but the phenotypes develop faster, presumably due to elevated cell turnover. Notably, the dependence of the manifestation of RNAi phenotypes on cell proliferation has been previously reported in planarian flatworms [31].

Table 3 Effects of temperature on biology of M. lignano, summary

\begin{tabular}{|c|c|c|c|c|}
\hline Characteristic & $20^{\circ} \mathrm{C}$ & $25^{\circ} \mathrm{C}$ & $30^{\circ} \mathrm{C}$ & $35^{\circ} \mathrm{C}$ \\
\hline Development (days) & $6-8$ & $4-5$ & $3-5$ & $3-4$ \\
\hline $\begin{array}{l}\text { Reproduction rate } \\
\text { (number of hatchlings) }\end{array}$ & $150-200$ & $310-430$ & $450-570$ & $320-410$ \\
\hline Regeneration (days) & 8 & 5 & 3 & 3 \\
\hline Heat shock response & $\mathrm{n} / \mathrm{a}$ & ns & 2-fold & $>20$ fold \\
\hline $\begin{array}{l}\text { Mlig-ddx39 RNAi, days } \\
\text { until lethality }\end{array}$ & $16-17$ & $9-10$ & $7-8$ & $\mathrm{n} / \mathrm{a}$ \\
\hline $\begin{array}{l}\text { Mlig-sperm1 RNAi, } \\
\text { percentage of animals } \\
\text { with enlarge testes at day } 4 .\end{array}$ & 0 & 25 & 85 & $\mathrm{n} / \mathrm{a}$ \\
\hline
\end{tabular}

\section{Conclusions}

In this study, we show that simple temperature control can significantly benefit a wide range of experiments using the flatworm model organism Macrostomum lignano. Based on our results and experience, we propose the following: (1) use $4{ }^{\circ} \mathrm{C}$ for storing the eggs and keeping them prior to microinjections; (2) use $20^{\circ} \mathrm{C}$ for standard cultures that do not need rapid expansion, thus reducing the frequency of transferring the animals to a fresh food source; (3) use $25^{\circ} \mathrm{C}$ for cultures that need to be quickly expanded and for the eggs that need to be hatched faster, for example microinjected eggs; (4) use $25^{\circ} \mathrm{C}$ or $30^{\circ} \mathrm{C}$ for RNAi experiments to observe the desired phenotype faster.

\section{Acknowledgements}

We thank Stijn Mouton for valuable comments on the manuscript. The DV1 line used in this study is a gift from Schärer laboratory.

\section{Funding}

This work was supported by the European Research Council Starting Grant (MacModel, grant no. 310765) to EB. KU was supported by the project 03242019-0040 from the Russian State Budget. The work on heat shock response was partially supported by the Russian Foundation for Basic Research (RFBR, grant no. 18-34-00288)

\section{Availability of data and materials}

The datasets supporting the conclusions of this article are included within the article.

\section{Authors' contributions}

$J W, K U, L G$ and EB designed the study. JW, KU and LG performed experiments. JW, LG and EB analyzed the results. JW and EB wrote the manuscripts. All authors read and approved the final manuscripts.

\section{Ethics approval and consent to participate}

Not applicable.

\section{Consent for publication}

Not applicable.

\section{Competing interests}

The authors declare that they have no competing interests.

\section{Publisher's Note}

Springer Nature remains neutral with regard to jurisdictional claims in published maps and institutional affiliations.

\footnotetext{
Author details

${ }^{1}$ European Research Institute for the Biology of Ageing, University of Groningen, University Medical Center Groningen, Antonius Deusinglaan 1, 9713AV, Groningen, The Netherlands. ${ }^{2}$ Institute of Cytology and Genetics, Prospekt Lavrentyeva 10, 630090 Novosibirsk, Russia.

Received: 20 November 2018 Accepted: 5 February 2019

Published online: 12 February 2019

\section{References}

1. Egger B, Gschwentner R, Rieger R. Free-living flatworms under the knife: past and present. Dev Genes Evol. 2007;217:89-104.

2. Umesono Y, Tasaki J, Nishimura K, Inoue T, Agata K. Regeneration in an evolutionarily primitive brain - the planarian Dugesia japonica model. Eur J Neurosci. 2011;34:863-9.

3. Rink JC. Stem cell systems and regeneration in planaria. Dev Genes Evol. 2013;223:67-84.
} 
4. Dattani A, Sridhar D, Aziz AA. Planarian flatworms as a new model system for understanding the epigenetic regulation of stem cell pluripotency and differentiation. Semin Cell Dev Biol. 2018;S1084-9521(17):30441-X.

5. Cebrià F, Adell T, Saló E. Rebuilding a planarian: from early signaling to final shape. Int J Dev Biol. 2018;62:537-50.

6. Ladurner P, Schärer L, Salvenmoser W, Rieger RM. A new model organism among the lower Bilateria and the use of digital microscopy in taxonomy of meiobenthic Platyhelminthes: Macrostomum lignano, n. Sp. (Rhabditophora, Macrostomorpha). J Zool Syst Evol Res. 2005:43:114-26.

7. Mouton S, Wudarski J, Grudniewska M, Berezikov E. The regenerative flatworm Macrostomum lignano, a model organism with high experimental potential. Int J Dev Biol. 2018;62:551-8.

8. Egger B, Ladurner P, Nimeth K, Gschwentner R, Rieger R. The regeneration capacity of the flatworm Macrostomum lignano - on repeated regeneration, rejuvenation, and the minimal size needed for regeneration. Dev Genes Evol. 2006;216:565-77.

9. Nimeth KT, Egger B, Rieger R, Salvenmoser W, Peter R, Gschwentner R Regeneration in Macrostomum lignano (Platyhelminthes): cellular dynamics in the neoblast stem cell system. Cell Tissue Res. 2007;327:637-46.

10. Wasik K, Gurtowski J, Zhou X, Ramos OM, Delás MJ, Battistoni G, et al. Genome and transcriptome of the regeneration-competent flatworm. Macrostomum lignano Proc Natl Acad Sci. 2015;112:12462-7.

11. Grudniewska M, Mouton S, Simanov D, Beltman F, Grelling M, De Mulder K, et al. Transcriptional signatures of somatic neoblasts and germline cells in Macrostomum lignano. Elife [Internet]. 2016;5:e20607.

12. Wudarski J, Simanov D, Ustyantsev K, de Mulder K, Grelling M, Grudniewska M, et al. Efficient transgenesis and annotated genome sequence of the regenerative flatworm model Macrostomum lignano. Nat Commun. 2017:8:2120.

13. Morris J, Nallur R, Ladurner P, Egger B, Rieger R, Hartenstein V. The embryonic development of the flatworm Macrostomum sp. Dev Genes Evol. 2004;214:220-39.

14. Schmidt-Nielsen K. Animal physiology: adaptation and environment: Cambridge University Press; 1997.

15. Stetter KO. Hyperthermophiles in the history of life. Philos Trans R Soc B Biol Sci. 2006;361:1837-43.

16. Cossins A. Temperature biology of animals. Springer Science \& Business Media; 2012.

17. Nespolo RF. Lardies M a, Bozinovic F. Intrapopulational variation in the standard metabolic rate of insects: repeatability, thermal dependence and sensitivity (Q10) of oxygen consumption in a cricket. J Exp Biol. 2003;206:4309-15.

18. Dunlap KD, Smith GT, Yekta A. Temperature dependence of Electrocommunication signals and their underlying neural rhythms in the weakly electric fish. Apteronotus leptorhynchus. 2000;2000:152-62.

19. Navas CA, James RS, Wakeling JM, Kemp KM, Johnston IA. An integrative study of the temperature dependence of whole animal and muscle performance during jumping and swimming in the frog Rana temporaria. J Comp Physiol B. 1999;169:588-96.

20. Richter K, Haslbeck M, Buchner J. The heat shock response: life on the verge of death. Mol Cell. 2010;40:253-66.

21. Jolly C. Role of the heat shock response and molecular chaperones in oncogenesis and cell death. J Natl Cancer Inst. 2000;92:1564-72.

22. Janicke T, Marie-Orleach L, De Mulder K, Berezikov E, Ladurner P, Vizoso DBBDB, et al. Sex allocation adjustment to mating group size in a simultaneous hermaphrodite. Evolution. 2013;67:3233-42.

23. Zadesenets KS, Vizoso DB, Schlatter A, Konopatskaia ID, Berezikov E, Schärer $L$, et al. Evidence for karyotype polymorphism in the free-living flatworm, macrostomum lignano, a model organism for evolutionary and developmental biology. PLoS One. 2016;11:e0164915.

24. Mouton S, Grudniewska M, Glazenburg L, Guryev V, Berezikov E. Resilience to aging in the regeneration-capable flatworm Macrostomum lignano. Aging Cell. 2018:e12739.

25. Grudniewska M, Mouton S, Grelling M, Wolters AHG, Kuipers J, Giepmans $B N G$, et al. A novel flatworm-specific gene implicated in reproduction in Macrostomum lignano. Sci Rep. 2018;8:3192.

26. Rieger R, Gehlen M, Haszprunar G, Holmlund M, Legniti A, Salvenmoser W et al. Laboratory cultures of marine Macrostomida (Turbellaria). Fortschr Zool. 1988;36.

27. De Mulder K, Pfister D, Kuales G, Egger B, Salvenmoser W, Willems M, et al. Stem cells are differentially regulated during development, regeneration and homeostasis in flatworms. Dev Biol. 2009:334:198-212.

28. Hu PJ. Dauer. WromBook. 2007;1-19.
29. Sulston J and JH. Methods, The nematode C. elegans. Wood WB, editor. Cold Spring Harbor Laboratory Press, Cold Spring Harbor, NY; 1988.

30. Hammoudi N, Torre C, Ghigo E, Drancourt M. Temperature affects the biology of Schmidtea mediterranea. Sci Rep. 2018:8:14934.

31. Takano T, Pulvers JN, Inoue T, Tarui H, Sakamoto H, Agata K, et al. Regeneration-dependent conditional gene knockdown (Readyknock) in planarian: demonstration of requirement for Djsnap-25 expression in the brain for negative phototactic behavior. Dev Growth Differ [Internet]. 2007; 49:383-94.

\section{Ready to submit your research? Choose BMC and benefit from:}

- fast, convenient online submission

- thorough peer review by experienced researchers in your field

- rapid publication on acceptance

- support for research data, including large and complex data types

- gold Open Access which fosters wider collaboration and increased citations

- maximum visibility for your research: over $100 \mathrm{M}$ website views per year

At BMC, research is always in progress.

Learn more biomedcentral.com/submissions 